\title{
Ultimate Strength of the Buoy Structure due to the Loads Arise from the Tanker and Mooring Lines
}

\author{
Murdjito $^{\mathrm{a}, *}$, Resy Agatya ${ }^{\mathrm{b}}$ and Handayanu ${ }^{\mathrm{a}}$ \\ a) Assistant Professor, Department of Ocean Engineering, Institut Teknologi Sepuluh Nopember, Kampus ITS - Sukolilo, Surabaya 60111, \\ Indonesia \\ b) Student, Department of Ocean Engineering, Institut Teknologi Sepuluh Nopember, Kampus ITS - Sukolilo, Surabaya 60111, Indonesia \\ *Corresponding author: murdjito@oe.its.ac.id
}

\begin{abstract}
A study was conducted to evaluate the ultimate strength of a 40 ton buoy induced by the dynamic loads arising from a 120,000 DWT Aframax tanker and mooring lines. The buoy is operated at Bangka Strait offshore oil terminal. The evaluation was commenced by analyzing the motion characteristics of the buoy and tanker due to environmental excitations, both in free floating conditions. This is continued by the simulation and time-domain analysis of connected buoy and tanker to observe the hawsers and mooring line tension intensities. The corresponding results show the largest tension occurs in the in-line configuration with the tanker in ballast condition, where hawsers tension reaches $1282.58 \mathrm{kN}$ with a safety factor of 2.23 and mooring line tension $1974.18 \mathrm{kN}$ with a safety factor of 3.20. The resulting tensions were further applied as input data for structural modeling using FEM to find out the stresses develop on the buoy structure. Results of this modeling reveal the maximum value of stress experienced by the buoy structure is approaching 184.28 MPa, which is below allowable stress of 200 $\mathrm{MPa}$. Following this, the ultimate stress of $450 \mathrm{MPa}$ will be violated by $143 \%$ incremental load above the maximum, namely 3,116.67 kN and 4,797.26 kN due to the hawsers and mooring line. This fact suggests that the structure is unlikely to experience ultimate failure if merely operated in the current operational site.
\end{abstract}

Keywords: buoy, tanker, mooring system, tensions, ultimate stress

\section{INTRODUCTION}

One of the energy sources that cannot be separated from human life is petroleum. The amount of needs to be met is not proportional to the available petroleum resources. In recent years, petroleum exploration and exploitation activities have begun to penetrate deeper water regions $[1,2]$. Oil drilling at sea should be supported by good operational infrastructure and facility. Tanker is one type of floating facility that is used to transport and distribute the product either in the form of oil, gas or chemical liquids. In this case the tanker played a major role in the distribution of oil.
During the process of loading and offloading at sea, a tanker requires a mooring system to maintain it stays in the intended position.

Buoy is a floating structure widely employed to moor the tanker at offshore terminals [3,4], composing a single buoy mooring (SBM) system as shown in Fig. 1 [5]. A buoy should be able to withstand the loads that develop from the tanker when moored during the loading and off-loading process. If this process fails then the distribution activity will stop and causes substantial losses. Because of the importance of the role of buoy mooring, the strength of the system should be assured. Therefore analysis on maximum stress that may occurs in buoy mooring is required for the safety of a system in the exploration and exploitation of petroleum at the sea.

This paper addresses a study carried out to evaluate the buoy structure strength. Specifically the study has been performed on an SBM system comprising a 40 ton buoy in combination with a 120,000 DWT Aframax tanker. The SBM system is operated at Bangka Strait oil terminal. The study is initiated by the evaluation of free floating motion characteristics of the tanker and buoy under environmental load effects. This is followed by the simulation of buoytanker as a combined moored system to generate the tension and buoy structural loads. Finally, the observation of buoy strength against the applied loads.

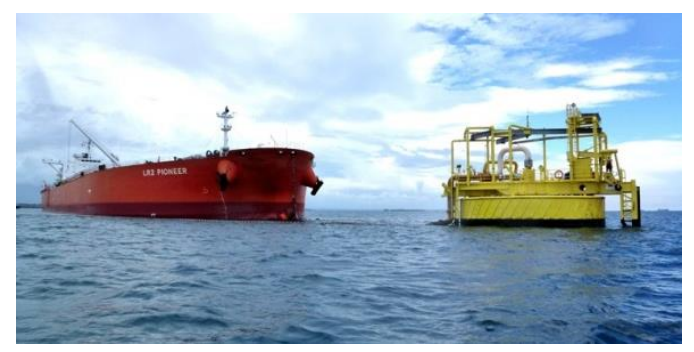

Figure 1. Single buoy mooring system [5] 


\section{METHODOLOGY AND MATERIALAS}

\subsection{Literature Study}

The literature study was conducted to obtain references and resources of theories and technical practices necessary to accomplish the evaluation and analysis. Sources used cover the text books, lecture materials, journals, previous research, and codes related to the study.

\subsection{Data Collection}

Data for this study has been collected from various sources, namely the literatures as described in sub-section 2.1 and industrial project documents. The required data includes tanker dimensions, buoy dimensions, mooring line as well as hawser properties and specifications, as presented sequentially in Tables 1-4.

Table 1. Principal dimension of the 120,000 DWT tanker

\begin{tabular}{|c|c|c|}
\hline Parameter & Full Load & Ballast \\
\hline Length $(\mathrm{m})$ & 256 & 256 \\
\hline Breadth $(\mathrm{m})$ & 43 & 43 \\
\hline Draft $(\mathrm{m})$ & 17 & 7.8 \\
\hline KG $(\mathrm{m})$ & 11.72 & 10.632 \\
\hline Displacement (ton) & 141126 & 65700 \\
\hline Wind longitudinal area $\left(\mathrm{m}^{2}\right)$ & 946 & 1342 \\
\hline Wind transverse area $\left(\mathrm{m}^{2}\right)$ & 2142 & 4285 \\
\hline
\end{tabular}

Table 2. Principal dimension of the buoy

\begin{tabular}{|c|c|c|c|}
\hline \multicolumn{3}{|c|}{ Buoy Data } \\
\hline Diameter (m) & \multicolumn{3}{|c|}{1.30} \\
\hline Draft (m) & \multicolumn{3}{|c|}{3.05} \\
\hline Height (m) & \multicolumn{3}{|c|}{40} \\
\hline Weight (ton) & \multicolumn{3}{|c|}{$\mathrm{Z}$} \\
\hline \multirow{2}{*}{ Center of Gravity (m) } & $\mathrm{X}$ & $\mathrm{Y}$ & 1.45 \\
\cline { 2 - 4 } & 0 & 0 & $\mathrm{Z}$ \\
\hline \multirow{2}{*}{ Radius of Gyration (m) } & $\mathrm{X}$ & $\mathrm{Y}$ & 2.693 \\
\cline { 2 - 4 } & 2.098 & 2.098 & \\
\hline
\end{tabular}

Tabel 3. Mooring line properties and specification

\begin{tabular}{|c|c|c|}
\hline Component & Unit & Value \\
\hline Mooring Chain & & \\
\hline Type & $\sim$ & Studless \\
\hline Diameter & $\mathrm{mm}$ & 92 \\
\hline Length of mooring chain & $\mathrm{m}$ & 95 \\
\hline Anchor Line & & \\
\hline Type & $\sim$ & Studless \\
\hline Length of @ anchor line & $\mathrm{m}$ & 55 \\
\hline Diameter & $\mathrm{mm}$ & 105 \\
\hline MBL & ton & 892.25 (Grade 3) \\
\hline
\end{tabular}

Table 4. Hawser properties and specifications

\begin{tabular}{|c|c|c|c|}
\hline \multicolumn{3}{|c|}{ Hawser Data } \\
\hline Material & \multicolumn{3}{|c|}{ Nylon Braidline 2 $856 \mathrm{~mm}$} \\
\hline Length (m) & \multicolumn{3}{|c|}{146} \\
\hline MBL (ton) & \multicolumn{3}{|c|}{197.15} \\
\hline Axial stiffness (ton) & $\mathrm{X}$ & $\mathrm{Y}$ & $\mathrm{Z}$ \\
\hline \multirow{2}{*}{$\begin{array}{c}\text { Fairlead coordinates on buoy } \\
\text { relative to buoy COG (m) }\end{array}$} & -2.00 & 0.00 & 2.74 \\
\hline
\end{tabular}

\begin{tabular}{|c|c|c|c|}
\hline $\begin{array}{c}\text { Fairlead coordinates on tanker } \\
\text { relative to tanker COG }(\mathrm{m})\end{array}$ & -5.00 & 0.00 & 24.00 \\
\hline
\end{tabular}

In addition to the above, the current study also requires data related to environment of the operational. As its is mentioned in the introduction, the operational site is at Bangka Strait, as depicted in the map of Fig. 2. The corresponding environmental data is as listed in Table 5.

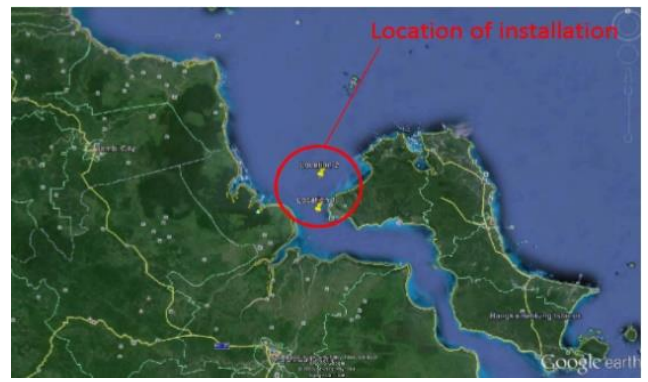

Figure 2. Operation site of the SBM system

Table 5. Environmental data of the operational site

\begin{tabular}{|l|c|}
\hline \multicolumn{1}{|c|}{ Element } & Intensity \\
\hline Lowest Astronomical Tide (LAT) $(\mathrm{m})$ & 0.18 \\
\hline Highest Astronomical Tide (HAT) $(\mathrm{m})$ & 3.98 \\
\hline Water depth $(\mathrm{m})$ & 54.0 \\
\hline Max. significant $H s$ wave height $(\mathrm{m})$ & 3.55 \\
\hline Max. peak period $T p(\mathrm{sec})$ & 9.15 \\
\hline Maximum wind speed $(\mathrm{m} / \mathrm{s})$ & 23.91 \\
\hline Maximum current speed $(\mathrm{m} / \mathrm{s})$ & 2.63 \\
\hline
\end{tabular}

\subsection{Buoy and Tanker Modeling}

Modeling of hull forms are carried out for both the tanker and the buoy by employing MAXSURF software. Modeling here aims at obtaining the ordinate of discrete points and hierarchical data of the hull forms. Further, the ordinates so generated by MAXSURF are used as input data to the frequency-domain (FD) software. This software assist in defining the hull form to be utilized in computing the motion of floating structure. Output of this software includes the motion response amplitude operators (RAOs), added mass and hydrodynamic damping data in FD software.

The hull forms already created using the aforementioned softwares are validated based on hydrostatic data obtained from the initial design. If the validation is considered unsatisfactory, then the hull forms will be redesigned to resemble more closely with the original design. The hull forms are checked for compliance with the displacement and other hydrostatic parameters.

\subsection{SBM System Simulation in Time-Domain}

Following the previously mentioned modeling, the SBM system comprising of tanker and buoy with the supporting mooring lines and hawser is composed to represent actual operation. When the system composition is ready it is then simulated in the-domain to evaluate its dynamic behaviors under the prevalent environmental loads [6]. 
Simulation is performed with the aid of OrcaFlex software. For this input data is obtained from the output of FD software combined with the environmental data. Output of the simulation presents the dynamic behaviors of the system, including the tension intensities develop on the mooring lines and hawser.

\subsection{Buoy Structure Strength Analysis}

The tensions develop on the mooring lines and the hawser as obtained from the time-domain simulation are to be applied in the buoy structure analysis. The analysis is conducted with an assistance of FEM software. Common procedure is followed, right from structure meshing, definition of load boundary conditions, as well as load variations. In this regards the applied loads are amplified to a certain degree hence the ultimate failure is observed.

\section{RESULTS AND DISCUSSIONS}

\subsection{Hull Models and Validation}

The 120,000 DWT Aframax tanker hull has been modeled using the MAXSURF and FD softwares as exhibited, respectively, in Figs. 3 and 4. Whereas as, due to its simple configuration, the buoy is only modeled using FD software, as depicted in Fig. 5.

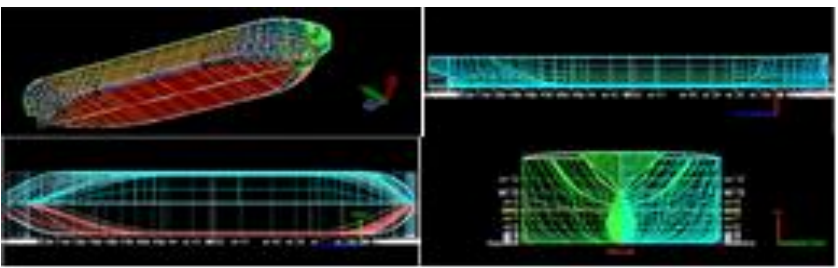

Figure 3. Tanker hull model developed by MAXSURF
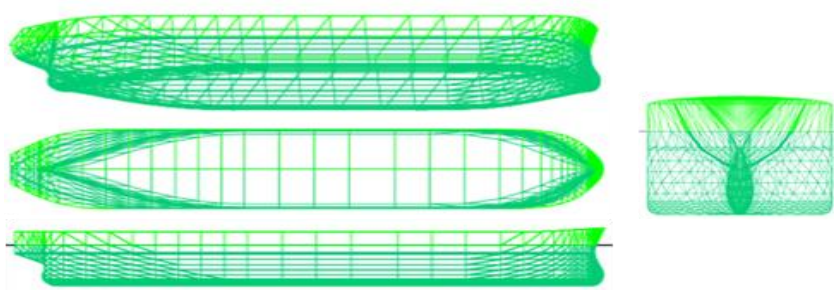

Figure 4. Tanker hull model developed by FD software

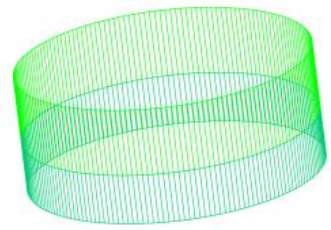

Figure 5. Buoy hull model developed by FD software

Based on the hull form generations hydrostatic computations of the tanker and buoy are then performed. The validation of the hull forms follows by comparing the hydrostatic data derived from software modeling and the initial data. According to ABS 2012 [7] validation is met when the difference in values of a number peculiar hydrostatic parameters do not exceed $2.0 \%$.

For the current study results of validation are presented in Tables 5-7. In all cases, namely tanker in full load and ballast condition as well as the buoy in operating condition, no difference exceeds $2.0 \%$. Therefore the hull form validation is satisfied.

Table 5. Validation of tanker in full load condition

\begin{tabular}{|c|c|c|c|c|}
\hline Parameter & Data & MAXSURF & FD Sftwr & Differ \\
\hline Displacement & 141,126 & 142,177 & 141,817 & $0.253 \%$ \\
\hline WPA & - & 9,872 & 9860 & $0.118 \%$ \\
\hline KMT & - & 18,12 & 18,11 & $0.028 \%$ \\
\hline KML & - & 328,72 & 328,73 & $0.002 \%$ \\
\hline BMT & - & 10,07 & 10,06 & $0.099 \%$ \\
\hline BML & - & 320,68 & 320,66 & $0.006 \%$ \\
\hline
\end{tabular}

Table 6. Validation of tanker in ballast load condition

\begin{tabular}{|c|c|c|c|c|}
\hline Parameter & Data & Maxsurf & FD Sftwr & Differ \\
\hline Displacement & 66,700 & 67,685 & 67,453 & $0.344 \%$ \\
\hline WPA & - & $8,969.6$ & $8,957.2$ & $0.137 \%$ \\
\hline KMT & - & 22.91 & 22.89 & $0.065 \%$ \\
\hline KML & - & 514.32 & 514,70 & $0.074 \%$ \\
\hline BMT & - & 18.89 & 18.88 & $0.095 \%$ \\
\hline BML & - & 510.31 & 510.69 & $0.074 \%$ \\
\hline
\end{tabular}

Table 7. Validation of the buoy

\begin{tabular}{|c|c|c|c|c|}
\hline \multicolumn{2}{|c|}{ Parameter } & Data & FD Sftwr & Differ \\
\hline \multicolumn{2}{|c|}{ Displacement } & 60.79 & 60.74 & $0.1 \%$ \\
\hline \multicolumn{2}{|c|}{ Draft } & 1.3 & 1.3 & $0.0 \%$ \\
\hline \multirow{2}{*}{$\begin{array}{c}\text { Center Of } \\
\text { Grafity }\end{array}$} & $\mathrm{x}$ & 0 & 0 & $0.0 \%$ \\
\cline { 2 - 5 } & $\mathrm{y}$ & 0 & 0 & $0.0 \%$ \\
\cline { 2 - 5 } & $\mathrm{z}$ & 1.45 & 1.45 & $0.0 \%$ \\
\hline \multirow{2}{*}{$\begin{array}{c}\text { Radius Of } \\
\text { Gyration }\end{array}$} & $\mathrm{x}$ & 2.098 & 2.1 & $0.1 \%$ \\
\cline { 2 - 5 } & $\mathrm{y}$ & 2.098 & 2.1 & $0.1 \%$ \\
\cline { 2 - 5 } & $\mathrm{z}$ & 2.693 & 2.7 & $0.3 \%$ \\
\hline
\end{tabular}

\subsection{Motion Characteristics in Free Floating}

Frequency-domain analysis has been conducted to determine the characteristics of tanker and buoy motions in regular waves. In this respect the tanker and buoy are analyzed separately as a single body in free floating state. The tanker has been analyzed in full load and ballast load conditions induced by 5 wave headings, namely $0^{\circ}, 45^{\circ}, 90^{\circ}, 135^{\circ}$, and $180^{\circ}$, at wave frequency ranges from 0.1 up to $2.0 \mathrm{rad} / \mathrm{sec}$. Results of the analysis are presented in the form of RAO of 6 modes of motion, which are surge, sway, heave, roll, pitch and yaw.

With due respect to the presumed symmetrical form of the buoy, that is as a cylindrical structure, then the analysis is only conducted in one wave heading. Subsequently, there will be only 4 modes of motion RAOs are generated, which are surge, heave, pitch and yaw. 
Results of analysis for the tanker in full load conditions are presented in Figs. 6-8 for the translational mode of motions, those are surge, sway and heave. Larger surge motion occur in wave the direction of $0^{\circ}$ and $180^{\circ}$ with a maximum value of $0.97 \mathrm{~m} / \mathrm{m}$. Large sway motion is found in the wave heading of $90^{\circ}$ with a peak value of $0.99 \mathrm{~m} / \mathrm{m}$. The maximum heave motion is also observed in the wave direction of $90^{\circ}$ with value of $1.4 \mathrm{~m} / \mathrm{m}$.

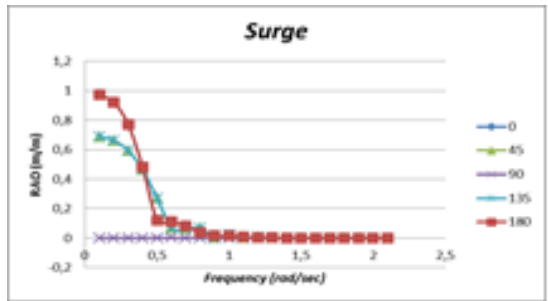

Figure 6. Surge RAO of tanker in full load condition

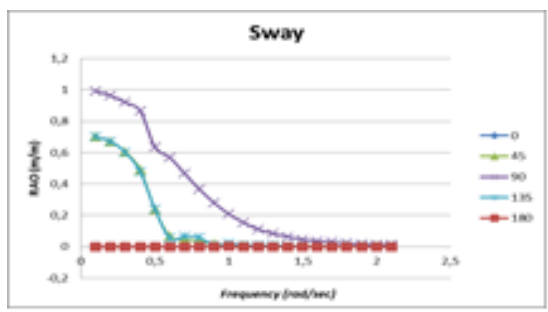

Figure 7. Sway RAO of tanker in full load condition

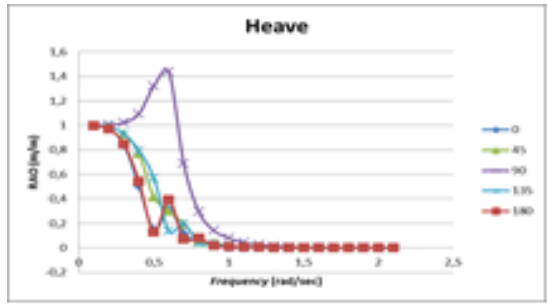

Figure 8. Heave RAO of tanker in full load condition

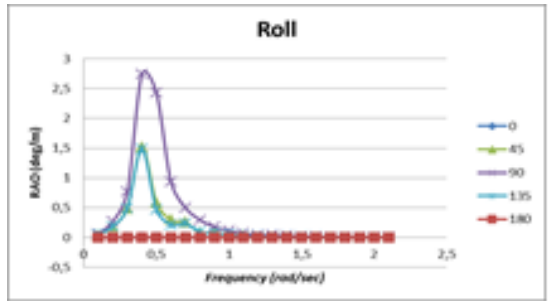

Figure 9. Roll RAO of tanker in full load condition

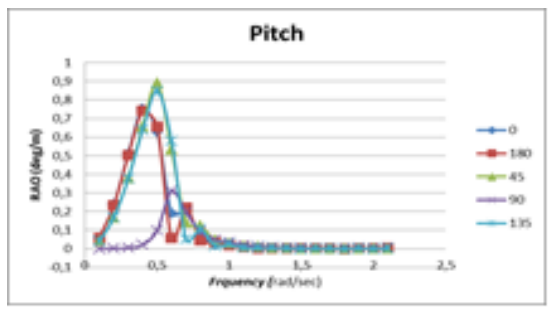

Figure 10. Pitch RAO of tanker in full load condition

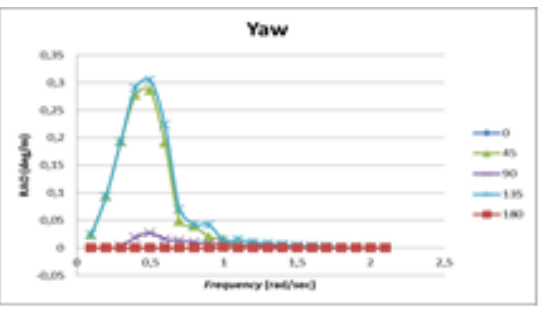

Figure 11. Yaw RAO of tanker in full load condition

The rotational motion modes of tanker in full load condition are shown in Figs. 9-11. Large roll motion occurs in the wave direction of $90^{\circ}$ with a maximum value of 2.7 $\mathrm{deg} / \mathrm{m}$. Large pitch RAO is due to the wave heading $45^{\circ}$ with a maximum value of $0.89 \mathrm{deg} / \mathrm{m}$. While the large yaw motion occurs in the wave direction of $135^{\circ}$ with a maximum value $0.3 \mathrm{deg} / \mathrm{m}$.

Results of motion analysis for the tanker with ballast load can be explained in the following. Interestingly the trends of surge of sway motion is remarkably similar to those in the case of full load condition. In the case of heave motion, large RAO also happen due to wave heading $90^{\circ}$, but the peak is less than that in full load, ie. only in the order of $1.11 \mathrm{~m} / \mathrm{m}$. The peak RAO of roll motion due to $90^{\circ}$ waves is found substantially higher than that in the case of full load, reaching $4.43 \mathrm{deg} / \mathrm{m}$. The peak of pitch RAO due to $45^{\circ}$ waves, on the other hand, is lower than that in full load, that is $0.79 \mathrm{deg} / \mathrm{m}$. While the yaw RAO having a maximum value of $0.32 \mathrm{deg} / \mathrm{m}$ almost similar with the case of full load also brought about $135^{\circ}$ wave propagation.

In most cases, either when the tanker is full load or in ballast load, the surge and sway peak frequencies are approaching the lowest range, ie. $0.1 \mathrm{rad} / \mathrm{sec}$. Natural frequencies of heave are about $0.75 \mathrm{rad} / \mathrm{sec}$. Whereas the natural frequencies for the three rotational modes are around 0.4 up to 0.6 rad.sec.

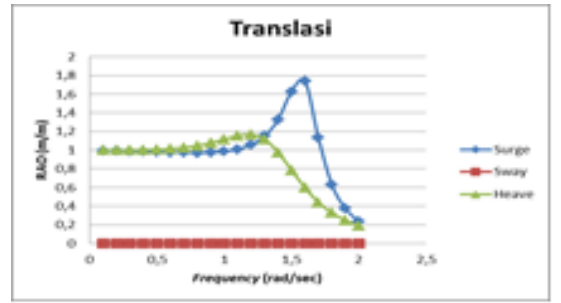

Figure 12. RAO of buoy translational motions

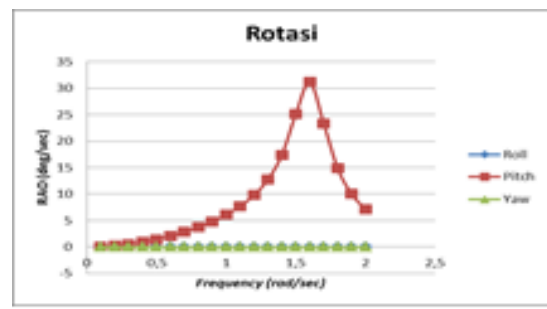

Figure 13. RAO of buoy rotational motions 
The RAO graphs of translational motion modes for the buoy is shown in Fig. 12. The maximum value of surge RAO notably larger than the heave, approaching $1.74 \mathrm{~m} / \mathrm{m}$ with the corresponding natural frequency of $1.7 \mathrm{rad} / \mathrm{sec}$. For the heave motions highest RAO value occurs at frequency of 1.2 $\mathrm{rad} / \mathrm{sec}$ with a value of $1.17 \mathrm{~m} / \mathrm{m}$. The sway motion has a zero value in all frequency range. However, due to the symmetrical form as already afore mentioned, this is in fact represented by the surge values, depending on the definition of wave propagation.

Figure 13 exhibits the RAO of rotational motion of the buoy. Again, it should be understood that due to the symmetrical principle hence the pitch and roll motions are equal, depending where the wave heading is considered. In this respect the maximum pitch, or could also be viewed as the roll, has a largest value in the order of $31 \mathrm{deg} / \mathrm{m}$, occur at the natural frequency of $1.6 \mathrm{rad} / \mathrm{sec}$. As it is expected no yaw motion is instigated by the wave actions.

\subsection{Results of SBM Simulation}

Modeling by OrcaFlex software aims at obtaining the maximum tensions on mooring lines and hawser. Here the SBM system is modeled in two schemes, namely in-line and in-between environmental load excitations, as can be seen in Fig. 14.

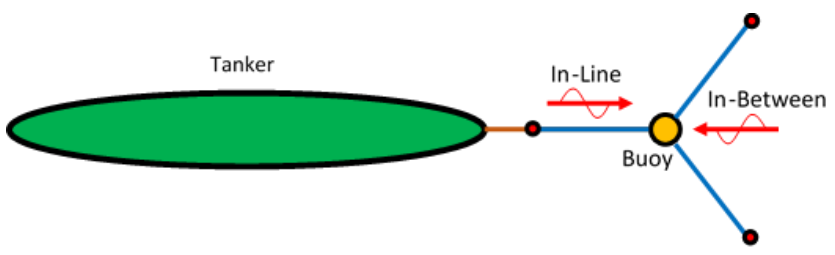

Figure 14. Definition of in-line and in-between for SBM system simulation

Table 8 . Tension and safety factor of system induced by in-between excitation with tanker in full load

\begin{tabular}{|c|c|c|c|c|c|c|}
\hline \multicolumn{2}{|c|}{ Name } & $\begin{array}{l}\text { End } \\
\text { Tension }\end{array}$ & $\begin{array}{l}\text { End } \\
\text { Tension }\end{array}$ & $\begin{array}{c}\mathrm{BL} \\
\text { (Ton) }\end{array}$ & $\begin{array}{l}\text { MBL } \\
\text { (Ton) }\end{array}$ & SF \\
\hline \multirow{2}{*}{ Hawser 1} & Tanker & 390.03 & 39.76 & 146 & 146 & 3.67 \\
\hline & Buoy & 389.95 & 39.75 & 146 & 146 & 3.67 \\
\hline \multirow{2}{*}{ Hawser 2} & Tanker & 390.03 & 39.76 & 146 & 146 & 3.67 \\
\hline & Buoy & 389.95 & 39.75 & 146 & 146 & 3.67 \\
\hline \multirow{2}{*}{$\begin{array}{c}\text { Mooring } \\
\text { Chain }\end{array}$} & Buoy & 1600.94 & 163.19 & 704.995 & 643.69 & 3.94 \\
\hline & Link Plate & 1523.61 & 155.31 & 704.995 & 643.69 & 4.14 \\
\hline \multirow{2}{*}{$\begin{array}{l}\text { Anchor } \\
\text { Chain } 1\end{array}$} & Link Plate & 79.48 & 8.10 & 892.25 & 824.27 & 101.73 \\
\hline & Anchor & 83.35 & 8.50 & 892.25 & 824.27 & 97.01 \\
\hline \multirow{2}{*}{$\begin{array}{l}\text { Anchor } \\
\text { Chain } 2\end{array}$} & Link Plate & 432.44 & 44.08 & 892.25 & 824.27 & 18.70 \\
\hline & Anchor & 427.76 & 43.60 & 892.25 & 824.27 & 18.90 \\
\hline \multirow{2}{*}{$\begin{array}{l}\text { Anchor } \\
\text { Chain } 3\end{array}$} & Link Plate & 432.82 & 44.12 & 892.25 & 824.27 & 18.68 \\
\hline & Anchor & 428.21 & 43.65 & 892.25 & 824.27 & 18.88 \\
\hline \multirow{2}{*}{$\begin{array}{l}\text { Sinker } \\
\text { Chain }\end{array}$} & Link Plate & 1985.05 & 202.35 & 892.25 & 824.27 & 4.07 \\
\hline & Sinker & 1986.43 & 202.49 & 892.25 & 824.27 & 4.07 \\
\hline
\end{tabular}

The simulation utilizing OrcaFlex takes input data of motion characteristics in free floating condition, mooring line properties, hawser properties, as well as simultaneous environmental loads brought about the wave, wind and current. Simulation is executed for 3 hours or 10,800 secs for both tanker in full and ballast loads. The criteria referred to in tension analysis is the one contained within API RP 2SK [8]. This particular code demands that the safety factor of 1.67 should be applied. Thus, the maximum permissible tensions develop on the mooring line and hawser should not exceed the value of the minimum breaking load (MBL) divided by the safety factor.

Table 9. Tension and safety factor of system induced by in-between excitation with tanker in ballast load

\begin{tabular}{|c|l|c|c|c|c|c|}
\hline \multicolumn{2}{|c|}{ Name } & $\begin{array}{c}\text { End } \\
\text { Tension } \\
(\mathrm{kN})\end{array}$ & $\begin{array}{c}\text { End } \\
\text { Tension } \\
(\text { Ton })\end{array}$ & $\begin{array}{c}\text { BL } \\
(\text { Ton })\end{array}$ & $\begin{array}{c}\text { MBL } \\
(\text { Ton) }\end{array}$ & SF \\
\hline \multirow{2}{*}{ Hawser 1 } & Tanker & 639.13 & 65.15 & 146 & 146 & 2.24 \\
\cline { 2 - 7 } & Buoy & 639.03 & 65.14 & 146 & 146 & 2.24 \\
\hline \multirow{2}{*}{ Hawser 2 } & Tanker & 639.13 & 65.15 & 146 & 146 & 2.24 \\
\cline { 2 - 7 } & Buoy & 639.03 & 65.14 & 146 & 146 & 2.24 \\
\hline \multirow{2}{*}{$\begin{array}{c}\text { Mooring } \\
\text { Chain }\end{array}$} & Buoy & 1971.72 & 200.99 & 705 & 643.69 & 3.20 \\
\cline { 2 - 7 } & Link Plate & 1891.07 & 192.77 & 705 & 643.69 & 3.34 \\
\hline \multirow{2}{*}{$\begin{array}{c}\text { Anchor } \\
\text { Chain 1 }\end{array}$} & Link Plate & 135.86 & 13.85 & 892.25 & 824.27 & 59.52 \\
\cline { 2 - 7 } & Anchor & 142.07 & 14.48 & 892.25 & 824.27 & 56.92 \\
\hline \multirow{2}{*}{$\begin{array}{c}\text { Anchor } \\
\text { Chain 2 }\end{array}$} & Link Plate & 538.53 & 54.90 & 892.25 & 824.27 & 15.02 \\
\cline { 2 - 7 } & Anchor & 532.42 & 54.27 & 892.25 & 824.27 & 15.19 \\
\hline \multirow{2}{*}{$\begin{array}{c}\text { Anchor } \\
\text { Chain 3 }\end{array}$} & Link Plate & 538.91 & 54.93 & 892.25 & 824.27 & 15.00 \\
\cline { 2 - 7 } & Anchor & 532.81 & 54.31 & 892.25 & 824.27 & 15.18 \\
\hline \multirow{2}{*}{$\begin{array}{c}\text { Sinker } \\
\text { Chain }\end{array}$} & Link Plate & 2269.53 & 231.35 & 892.25 & 824.27 & 3.56 \\
\cline { 2 - 7 } & Sinker & 2270.88 & 231.49 & 892.25 & 824.27 & 3.56 \\
\hline
\end{tabular}

Table 10. Tension and safety factor of system induced by in-line excitation with tanker in full load

\begin{tabular}{|c|l|c|c|c|c|c|}
\hline \multicolumn{2}{|c|}{ Name } & $\begin{array}{c}\text { End } \\
\text { Tension } \\
(\mathrm{kN})\end{array}$ & $\begin{array}{c}\text { End } \\
\text { Tension } \\
\text { (Ton) }\end{array}$ & $\begin{array}{c}\text { BL } \\
(\text { Ton) }\end{array}$ & $\begin{array}{c}\text { MBL } \\
(\text { Ton })\end{array}$ & SF \\
\hline \multirow{2}{*}{ Hawser 1 } & Tanker & 389.54 & 39.71 & 146 & 146 & 3.68 \\
\cline { 2 - 7 } & Buoy & 389.46 & 39.70 & 146 & 146 & 3.68 \\
\hline \multirow{2}{*}{ Hawser 2 } & Tanker & 389.54 & 39.71 & 146 & 146 & 3.68 \\
\cline { 2 - 7 } & Buoy & 389.46 & 39.70 & 146 & 146 & 3.68 \\
\hline \multirow{2}{*}{$\begin{array}{c}\text { Mooring } \\
\text { Chain }\end{array}$} & Buoy & 1599.78 & 163.08 & 705.00 & 643.69 & 3.95 \\
\cline { 2 - 7 } & Link Plate & 1523.69 & 155.32 & 705.00 & 643.69 & 4.14 \\
\hline \multirow{2}{*}{$\begin{array}{c}\text { Anchor } \\
\text { Chain 1 }\end{array}$} & Link Plate & 825.53 & 84.15 & 892.25 & 824.27 & 9.80 \\
\cline { 2 - 7 } & Anchor & 822.18 & 83.81 & 892.25 & 824.27 & 9.83 \\
\hline \multirow{2}{*}{$\begin{array}{c}\text { Anchor } \\
\text { Chain 2 }\end{array}$} & Link Plate & 175.73 & 17.91 & 892.25 & 824.27 & 46.01 \\
\cline { 2 - 7 } & Anchor & 167.73 & 17.10 & 892.25 & 824.27 & 48.21 \\
\hline \multirow{2}{*}{$\begin{array}{c}\text { Anchor } \\
\text { Chain 3 }\end{array}$} & Link Plate & 175.74 & 17.91 & 892.25 & 824.27 & 46.01 \\
\cline { 2 - 7 } & Anchor & 167.87 & 17.11 & 892.25 & 824.27 & 48.17 \\
\hline \multirow{2}{*}{$\begin{array}{c}\text { Sinker } \\
\text { Chain }\end{array}$} & Link Plate & 1854.79 & 189.07 & 892.25 & 824.27 & 4.36 \\
\cline { 2 - 7 } & Sinker & 1856.24 & 189.22 & 892.25 & 824.27 & 4.36 \\
\hline
\end{tabular}

Table 11. Tension and safety factor of system induced by in-line excitation with tanker in ballast load

\begin{tabular}{|c|l|c|c|c|c|c|}
\hline \multicolumn{2}{|c|}{ Name } & $\begin{array}{c}\text { End } \\
\text { Tension } \\
(\mathrm{kN})\end{array}$ & $\begin{array}{c}\text { End } \\
\text { Tension } \\
(\text { Ton })\end{array}$ & $\begin{array}{c}\text { BL } \\
(\text { Ton })\end{array}$ & $\begin{array}{c}\text { MBL } \\
(\text { Ton) }\end{array}$ & SF \\
\hline \multirow{2}{*}{ Hawser 1 } & Tanker & 641.39 & 65.38 & 146 & 146 & 2.23 \\
\cline { 2 - 7 } & Buoy & 641.29 & 65.37 & 146 & 146 & 2.23 \\
\hline \multirow{2}{*}{ Hawser 2 } & Tanker & 641.39 & 65.38 & 146 & 146 & 2.23 \\
\cline { 2 - 7 } & Buoy & 641.29 & 65.37 & 146 & 146 & 2.23 \\
\hline \multirow{2}{*}{$\begin{array}{c}\text { Mooring } \\
\text { Chain }\end{array}$} & Buoy & 1974.18 & 201.24 & 705.00 & 643.69 & 3.20 \\
\cline { 2 - 7 } & Link Plate & 1893.64 & 193.03 & 705.00 & 643.69 & 3.33 \\
\hline \multirow{2}{*}{$\begin{array}{c}\text { Anchor } \\
\text { Chain 1 }\end{array}$} & Link Plate & 1036.66 & 105.67 & 892.25 & 824.27 & 7.80 \\
\cline { 2 - 7 } & Anchor & 1033.60 & 105.36 & 892.25 & 824.27 & 7.82 \\
\hline \multirow{2}{*}{$\begin{array}{c}\text { Anchor } \\
\text { Chain 2 }\end{array}$} & Link Plate & 192.64 & 19.64 & 892.25 & 824.27 & 41.98 \\
\cline { 2 - 7 } & Anchor & 183.38 & 18.69 & 892.25 & 824.27 & 44.09 \\
\hline \multirow{2}{*}{$\begin{array}{c}\text { Anchor } \\
\text { Chain 3 }\end{array}$} & Link Plate & 192.63 & 19.64 & 892.25 & 824.27 & 41.98 \\
\cline { 2 - 7 } & Anchor & 183.38 & 18.69 & 892.25 & 824.27 & 44.10 \\
\hline \multirow{2}{*}{\begin{tabular}{c} 
Sinker Chain \\
\cline { 2 - 7 }
\end{tabular}} & Link Plate & 2101.80 & 214.25 & 892.25 & 824.27 & 3.85 \\
\cline { 2 - 7 } & Sinker & 2103.24 & 214.40 & 892.25 & 824.27 & 3.84 \\
\hline
\end{tabular}


Results of the simulation are presented in Tables 8-11. Primary attention is to be directed towards the tension loads induced by two hawsers and mooring chain onto the buoy. The largest tension loads are experienced by the buoy when the system is excited by in-between environmental load with the tanker being ballast loaded, as contained in Table 11. In this respect each hawser generate a tension of $641.29 \mathrm{kN}$ and the mooring chain incites some 1,974.18 kN. None the less, for all cases so observed eventually the resulting safety factors are found to satisfy the API criteria.

\subsection{Buoy Structure Behavior Under High Loads}

The technical drawing of the 40 ton buoy as the main object in the current study is illustrated in Fig. 15. This is displaying the transverse section of main body frame and vertical center shaft. The technical drawing was redrawn using a CAD software to be exported into the FEM software for structure evaluation.

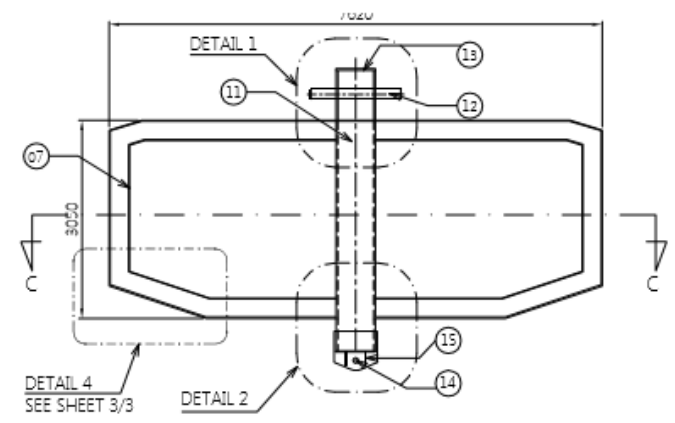

Figure 15. Technical drawing of the buoy structure

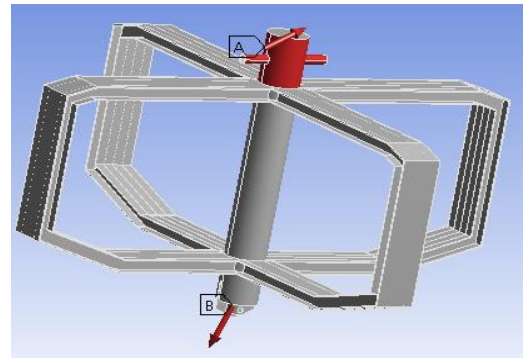

Figure 16. FEM model of the buoy and the applied loads

In the FEM software the CAD drawing is converted into the format appropriately generated for structural computation, as illustrated in Fig. 16. As can be seen, the structure is represented by four side ring frames attached to the center shaft. The loads from the two hawsers and the mooring line are applied, respectively, at the upper and lower part of the center shaft, specifically point A and B in Fig.16. Referring to the results in Table 11, the total intensity due to the two hawsers is $1,282.58 \mathrm{kN}$ and due to the mooring chain is $1,974.18 \mathrm{kN}$.

The buoy basic structure model is further processed into structural meshing. Here the structure is subdivided into a large number of elements, as shown in Fig. 17. Number of elements or meshing density and the distribution should be established on the basis of structure topology. Meshing density and its distribution will determine the accuracy of FEM computational results. Various factors affect the meshing density lead to the accuracy, ranging from stress gradients, loading types, boundary conditions, as well as element types and sizes $[9,10]$.

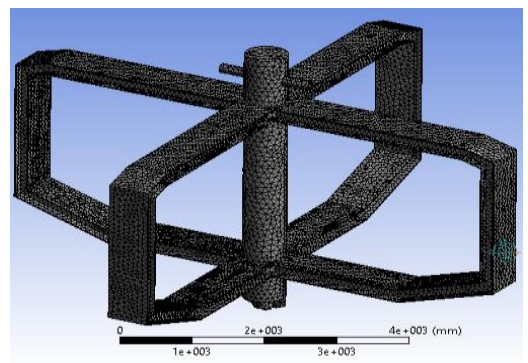

Figure 17. Buoy frame model meshing

In the current study triangular element type is selected for the model and then appropriate fine meshing is established. Meshing sensitivity subsequently performed to check the stress come up at a certain structure reference point. In this vein meshing revision has been conducted at least up to 9 iterations before the convergence value of reference stress is reached. The final model reveals structure meshing is composed out of 185,227 elements with average element size of 3.2 inches.

The later stage of structural model is the definition of boundary conditions. In the current case, the boundary condition of the lower part of the buoy center shaft at mooring chain connection is as displayed in Fig. 18. The buoy structure is designed to be constructed with steel material of ASTM A36 class, having a yield stress $\sigma_{y}$ of $250 \mathrm{MPa}$.

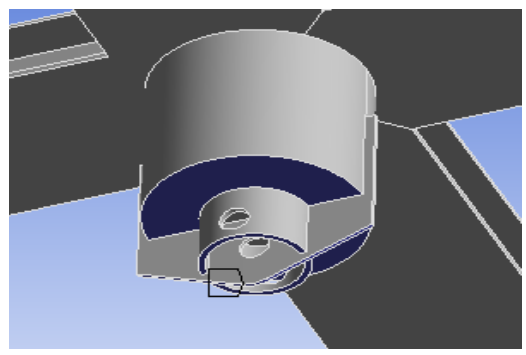

Figure 18 . Boundary condition at the chain connection

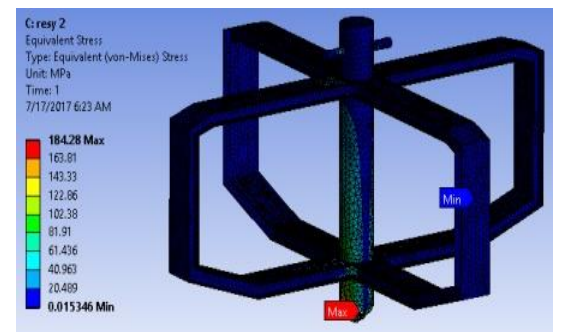

Figure 19. Global von Mises stress distribution on the buoy structure model 
Following the aforementioned stage execution of structural computation by FEM is carried out. This subsequently deliver the von Mises stress distribution on the global structure of the buoy as illustrated in Fig. 19. A maximum von Mises stress is found to be at the chain connection of the lower part of the center shaft in the order of 184.28 MPa. The more exact location of the maximum stress is depicted in Fig. 20.

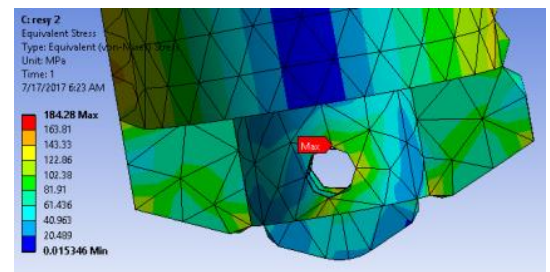

Figure 20. Specific location of maximum von Mises stress

Referring to the commonly applied rules or codes for offshore structure, such as ABS [7], the maximum von Mises stress develops owing to combined severe environmental load effects should not exceed $0.8 \sigma_{y}$. This limit for the currently studied buoy structure is $200 \mathrm{MPa}$. Comparing this with the result of FEM execution it is obvious that the maximum that the limit is not violated, that is $184.28 \mathrm{MPa}$ $<200 \mathrm{MPa}$. Therefore the structure could be confidently safe for operation in its designed site.

Never the less a further exploration still need to be conducted, that is in relation with finding out the ultimate strength of the structure. A common approach in this exploration is by adopting the incremental load scheme [10]. In short, the structure is to be induced by higher loads increased at some stages from the initially found maximum load. In this study three stages or load cases will be applied until the ultimate stress of $450 \mathrm{MPa}$ is exceeded. The three load cases with the corresponding increasing of tensions caused by hawsers and mooring line are displayed in Table 12. Load cases 1, 2 and 3 represent the increase in applied load of, respectively, $50 \%, 100 \%$ and $150 \%$ higher than the initial maximum load obtained from the previously described simulation.

Table 12. Load cases for ultimate stress exploration

\begin{tabular}{|c|c|c|c|}
\hline \multirow{2}{*}{ Load Case } & \multicolumn{2}{c|}{ Tension Force } \\
\cline { 2 - 4 } & $\begin{array}{c}\text { Hawser } \\
(\mathrm{kN})\end{array}$ & $\begin{array}{c}\text { Mooring } \\
\text { Chain }(\mathrm{kN})\end{array}$ \\
\hline \multicolumn{2}{|c|}{ Initial Max Load } & 1282.58 & 1974.18 \\
\hline Load Case 1 & $+50 \%$ & 1923.88 & 2961.26 \\
\hline Load Case 2 & $+100 \%$ & 2565.17 & 3948.35 \\
\hline Load Case 3 & $+150 \%$ & 3206.46 & 4935.44 \\
\hline
\end{tabular}

Ultimate stress exploration is conducted making use FEM by inducing incremental load scheme. The increasing of von Mises stress takes place on the chain connection is recorded and further plotted in the graph exhibited in Fig. 21 . In this figure, the blue curve indicates the increase in von
Mises stress in parallel to the raise of incremental load. The curve eventually intersect with the ultimate stress limit when the load is increased approximately up to $143 \%$ above the initial maximum load. This means the structure has an ultimate strength to withstand hawsers and mooring line loads up to, respectively, 3,116.67 kN and 4,797.26 kN.

For the sake of information, the FEM gives von Mises stress of some $461 \mathrm{MPa}$ when the maximum load is increased by $150 \%$. This fact demonstrate that the structure is very much unlikely to experience ultimate failure if operated merely in the current location of Bangka Strait.

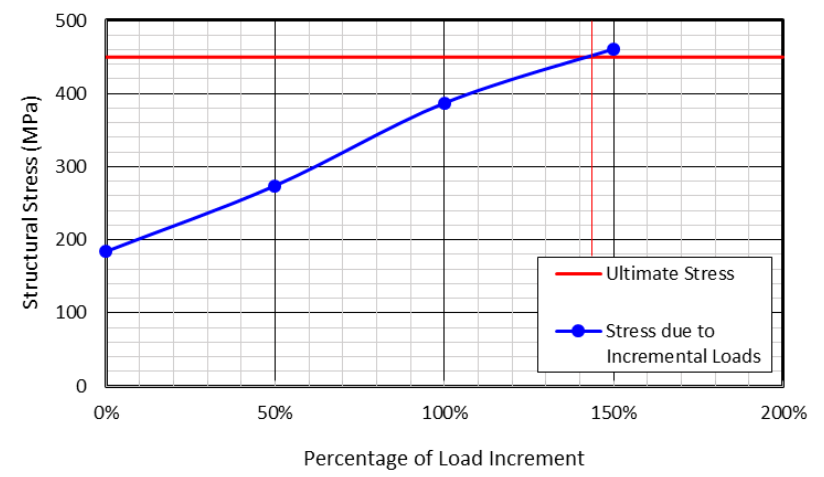

Figure 21. The increase in von Mises stress as function of load increment

\section{CONCLUSIONS}

The evaluation conducted on the SBM system operated to support an offshore terminal in Bangka Strait suggests the following points:

1. The tensions acting on the buoy structure come from effect of two hawsers and a mooring line. The largest tensions are found to be $641.29 \mathrm{kN}$ from each hawsers and $1974.18 \mathrm{kN}$ from the mooring line present when the system is excited by in-line environmental load with the tanker in ballast condition. The corresponding safety factors are 2.23 and 3.20, where both meet the criteria of API RP 2SK which requires safety factor should be higher than 1.67 .

2. The combined maximum tensions from the two hawsers and mooring line causes a von Moses stress of 184.28 MPa to develop lower shaft of the buoy around the mooring chain connection. The maximum maximum stress that occurs do not exceed the allowable stress of $200 \mathrm{MPa}$. Hence the structure is considered safe for operation in the severest condition of operational site.

3. The ultimate stress of $450 \mathrm{MPa}$ on the structure will be violated if the maximum load is incrementally increased up to $143 \%$. This means the structure has an ultimate strength to withstand hawsers and mooring line loads up to, respectively, $3,116.67 \mathrm{kN}$ and 4,797.26 kN. This finding indicates the structure is immensely unli- 
kely to experience ultimate failure if operated merely in the current location of Bangka Strait.

\section{ACKNOWLEDGEMENTS}

The authors are indebted to PT ZEE Indonesia for supporting the current study by facilitating the use of related softwares. Appreciations are conveyed to all parties who have provided assistances to the current study.

\section{REFERENCES}

1. Dragani, J. and Kotenev, M.: Deepwater development: what past performance says about the future. The Way Ahead, Vol. 9-1, pp.8-9, 2013

2. GBI: Offshore drilling industry to 2016 - rapidly rising demand for hydrocarbons expected to boost offshore drilling in ultra-deepwater and harsh-weather environments. Report Code: GBIGE00053MR, GBI Research, Dec. 2011

3. Chang, Z.Y. et al.: Deployment simulation of mooring buoy system. Applied Mechanics and Materials, Vol. 141, pp. 98-102, 2012

4. Versluis, J.: Exposed location single buoy mooring. Offshore Technology Conference, Paper: OTC-3805MS, Houston, TX, 5-8 May 1980
5. World Maritime News: Leighton Offshore Completes Tanzania Single Point Mooring Project. Retrieved from http://worldmaritimenews.com/archives/69495/ on 12 July 2017 at $15: 16$

6. Arda, Djatmiko, E.B. and Murdjito: A study on the effect of semi-submersible drilling rig motions with variation in mooring line pre-tension to the safety of drilling riser. Proc. of the $8^{\text {th }}$ International Conference on Marine Technology MARTEC 2012, Kuala Terengganu, Malaysia, 20 - 22 October 2012

7. ABS: Rules for Building and Classing Mobile Offshore Drilling Units. American Bureau of Shipping, ABS Plaza, Houston, TX, USA, 2012

8. API: Design and Analysis of Station Keeping System for Floating Structures, API RP 2 SK. American Petroleum Institute, Washington DC, 2005

9. Prastianto, R.W., Otsuka, K. and Ikeda, Y.: On the multi-mode VIV response of a small-long flexible horizontal cylinder in uniform flows. International Conference on Violent Flows (VF-2007), pp. 429-437, RIAM, Kyushu University, Fukuoka, Japan, 2007

10. Yuda, I D.G.A.S., Djatmiko, E.B. and Rosyid, D.M.: A study of the dynamic longitudinal hull structural responses and ultimate strength of drillship. Journal of Ocean, Mechanical and Aerospace - Science and Engineering, Vol. 17, pp. 1-8, March, 2015 